\title{
TREATMENT RESULTS OF METASTATIC KIDNEY CANCER PATIENTS INCLUDED IN NIVOLUMAB - NAME PATIENT PROGRAM (NPP) AT UNIVERSITY HOSPITAL CENTER ZAGREB
}

\author{
MARIJA GAMULIN ${ }^{1}$, MILENA GNJIDIĆ ${ }^{1}$, DENI RKMAN ${ }^{2}$ and MARKO BEBEK ${ }^{1}$ \\ ${ }^{1}$ Department of Oncology, University Hospital Center Zagreb, Zagreb, Croatia; \\ ${ }^{2}$ School of Medicine, University of Zagreb, Zagreb, Croatia
}

\begin{abstract}
Summary
Field of metastatic renal cell cancer (mRCC) treatments is now evolving at a rapid and unprecedented pace. Nivolumab prolongs survival in patients with metastatic kidney cancer with a favorable safety profile as demonstrated in the CheckMate 025 clinical trial. Nivolumab compared to everolimus prolonged survival in patients with mRCC while exibiting favorbale safety profile. In this study we present the results of nivolumab treatment in patients with mRCC within named patient program (NPP) at UHC Zagreb. In 30\% of included patients survival was longer than 30 months and $16.6 \%$ patients had a complete response.
\end{abstract}

KEYWORDS: Metastatic kidney cancer, nivolumab, second line

\section{REZULTATI LIJEČENJA BOLESNIKA S METASTATSKIM RAKOM BUBREGA NIVOLUMABOM - DONACIJSKIM PROGRAMOM NA IME BOLESNIKA (NPP) U KLINIČKOM BOLNIČKOM CENTRU ZAGREB}

\section{Sažetak}

Područje liječenja metastatskog raka bubrega (mRCC) je područje ubrzanog razvoja terapijskih mogućnosti. Nivolumab produljuje preživljenje bolesnika s metastatskim rakom bubrega uz dobar sigurnosni profil što je pokazano u kliničkoj studiji CheckMate025. Nivolumab u usporedbi s everolimusom produljuje preživljenje kod bolesnika sa mRCC uz povoljni sigurnosni profil lijeka. U ovoj analizi smo prikazali rezultate liječenja bolesnika nivolumabom u NPP u Kliničkom bolničkom centru Zagreb tijekom 2016. do 2018. 30\% bolesnika ima preživljenje dulje od 30 mjeseci, a 16.6\% je imalo kompletni odgovor na terapiju.

KLJUČNE RIJEČI: Metastatski rak bubrega, nivolumab, druga linija liječenja

\section{INTRODUCTION}

After decades of slow progress, the field of metastatic renal cancer (mRCC) treatments is now evolving at a rapid and unprecedented pace. Nivolumab is an anti-programmed death-1 (PD-1) receptor antibody (novel immune checkpoint inhibitor) that prolongs survival in patients with metastatic kidney cancer with a good safety profile, as demonstrated in the CheckMate 025 clinical randomized phase III trial. The median overall survival was 25.0 months with nivolumab and 19.6 months with everolimus(1). The hazard ratio for nivolumab versus everolimus was $0.73(98.5 \%$ $\mathrm{CI}, 0.57$ to $0.93 ; \mathrm{P}=0.002$ ). The objective response rate was greater with nivolumab than with evero- 
limus ( $25 \%$ vs. $5 \%$ ) (1). The median progressionfree survival was 4.6 months with nivolumab and 4.4 months with everolimus Grade 3 or 4 treatment-related adverse events occurred in $19 \%$ of patients receiving nivolumab and in $37 \%$ of patients receiving everolimus; the most common adverse event with nivolumab was fatigue (in $2 \%$ of patients), with everolimus it was anemia (in 8\%) (1). ESMO and NCCN guidelines recommended nivolumab as an option in the second-line therapy after failure of first-line antiangiogenic therapy and if nivolumab was not used as the first-line therapy $(2,3)$.

We wished to participate in the nivolumab donation program to improve the treatment of our patients without financially burdening the Croatian Health Insurance Fund.

\section{MATERIAL AND METHODS}

Patients with metastatic kidney cancer $(\mathrm{mRCC})$ received tyrosine kinase inhibitors (TKI) or temsirolimus as the first-line therapy, and subsequently, they received nivolumab $3 \mathrm{mg} / \mathrm{kg}$ NPP every two weeks from 2016 to 2018. In patients who did not have disease progression or grade 3 and 4 toxicity, nivolumab treatment was continued, funded by the Croatian Health Insurance. Patients are regularly monitored every three months with CT of the chest, abdomen, and pelvis, with bone analysis, laboratory tests (hematology, biochemistry, T4, TSH). The decision about the therapy continuation depended on adverse events and disease progression. We also respect patients' preference regarding cycle dynamics (cycles with occasional breaks in treatment), especially in patients who previously had one year of nivolumab therapy.

\section{RESULTS}

We treated 30 patients ( 22 men and 8 women) with $\mathrm{mRCC}$, who initially received TKI therapy with the median age at diagnosis of kidney cancer 60.2 ( \pm 9.79 years). Most patients belonged to intermediate-risk, according to the MSKCC risk group. As the first-line treatment, the majority of patients, 23 out of 30 received sunitinib, 6 out of 30 received pazopanib, and 1 out of 30 received temsirolimus. Nine patients $(30 \%)$ achieved survival over 30 months (31 \pm 0.95 months) after treatment with nivolumab as the second-line therapy. A total of 5 patients $(16.6 \%)$ had a complete response to nivolumab therapy. Grade 2 fatigue, according to common toxicity criteria (CTC) version 4 , was the most common side effect of treatment with nivolumab.

\section{DISCUSSION}

Nivolumab is the first immune-checkpoint inhibitor approved for second-line therapy of mRCC after progression on vascular endothelial growth factor (VEGF)-TKIs $(4,5)$. Nivolumab has clearly shown the benefit when compared to everolimus in second-line mRCC therapy $(1,4)$. We observed excellent treatment responses. Even though the treatment of advanced RCC has changed in recent years, longlasting complete remissions, although recorded, are exceptional with single immunotherapy agents and $\mathrm{mRCC}$ remains an incurable disease.

Further research is needed to better understand the criteria for selection of patients, to discover and better characterize potential biomarkers, to explore possibilities of to combinational therapies and to define optimal sequence of therapies in order to achieve the best outcome for patients.

\section{CONCLUSION}

In our limited, single-institution experience, nivolumab as a second-line agent, in patients who progressed on first-line antiangiogenic therapy, achieved favorable efficacy and toxicity profile similar to those observed in large clinical trials. Our definitive observations are limited due to a small number of included patients, and further research is needed to better characterize nivolumab efficacy and toxicity for every day clinical practice.

\section{REFERENCES}

1. Motzer JR, Escudier B, McDermott DF, George S, Hammers HJ, Srinivas S, et al. Nivolumab versus Everolimus in Advanced Renal Cell Carcinoma. N Engl J Med. 2015;373(19):1803-13.

2. [NCCN-Internet]. 2020 [accessed on 30 June 2019]. Available on: https://www.nccn.org/professionals/ physician_gls/pdf/kidney.pdf 
3. Escudier B, Porta C, Schmidinger M, Rioux-Leclercq N, Bex A,. Khoo V, et al. Renal cell carcinoma: ESMO Clinical Practice Guidelines for diagnosis, treatment and follow-up. Ann Oncol. 2019;30:706-20.

4. Stukalin I, Wells JC, Graham J, Yuasa T, Beuselinck B, Kollmansberger $\mathrm{C}$ et al. Real-world outcomes of nivolumab and cabozantinib in metastatic renal cell carcinoma: results from the International Metastatic Renal Cell Carcinoma Database Consortium. Curr Oncol. 2019;26(2):175-79.
5. Atkins MB, Tannir NM. Current and emerging therapies for first-line treatment of metastatic clear cell renal cell carcinoma. Cancer Treat Rev. 2018;70:127-37.

Corresponding author: Marija Gamulin, University Hospital Center Zagreb, Department of Oncology, Kišpatićeva 12, 10000 Zagreb, Croatia.e-mail:mgamulin8@gmail.com 